\title{
Determination of Ascorbic Acid, Rutin and Antioxidant Capacities of Wild Allium roseum from Italy
}

\author{
Anna Ida Fiaschi ${ }^{1}$, Daniela Cerretani ${ }^{1}$, Laura Moltoni ${ }^{1}$, Andrea Menchiari², Lucia Micheli $^{1}$ \\ ${ }^{1}$ Department of Medicine, Surgery and Neuroscience, University of Siena, Siena, Italy \\ ${ }^{2}$ Department of Business and Law, University of Siena, Siena, Italy \\ Email: michelil@unisi.it
}

How to cite this paper: Fiaschi, A.I., Cerretani, D., Moltoni, L., Menchiari, A. and Micheli, L. (2019) Determination of Ascorbic Acid, Rutin and Antioxidant Capacities of Wild Allium roseum from Italy. Pharmacology \& Pharmacy, 10, 271-282. https://doi.org/10.4236/pp.2019.105022

Received: April 8, 2019

Accepted: May 18, 2019

Published: May 21, 2019

Copyright $\odot 2019$ by author(s) and Scientific Research Publishing Inc. This work is licensed under the Creative Commons Attribution International License (CC BY 4.0).

http://creativecommons.org/licenses/by/4.0/

\begin{abstract}
This study is designed to investigate the antioxidant status and the presence of biologically-active compounds in Allium roseum L. and to compare the results with those of Allium sativum L. The content of thiosulfinates (Thio) and the levels of flavonols (quercetin and rutin), ascorbic acid (AA), glutathione reduced (GSH), glutathione oxidized (GSSG) and the antioxidant enzymes activities of glutathione peroxidase (GPx), glutathione reductase (GR) and catalase (CAT), were evaluated in bulbs, bulblets, flowers bulblets, leaves and flowers. Our study shows that bulbs of Allium roseum contain levels significantly higher of GSH, GSSG, AA, Thio, rutin and the activity of GPx and GR significantly higher than bulbs of Allium sativum. Moreover, the bulbs of Allium roseum show a significantly higher content of GPx, GR, CAT, GSH and GSSG than bulblets, flowers bulblets, leaves and flowers of Allium roseum. In Allium roseum, the greatest content of Thio is present in the flowers bulblets, while the levels of AA, quercetin and rutin are greater in the flowers. In conclusion, our result shows how Allium roseum exhibits antioxidant capabilities in all its fresh organs. The bulbs, bulblets, flowers bulblets, leaves and flowers are a good source of important bioactive compounds. Allium roseum possesses properties comparable to garlic indicating its possible nutritional and medicinal value.
\end{abstract}

\section{Keywords}

Rutin, Ascorbic Acid, Allium roseum, Allium sativum

\section{Introduction}

A healthy diet, rich in natural foods may help to prevent the development of 
several diseases [1]. Allium species (Alliaceae) have always been used as food or as medicinal plants in human history and several investigations have demonstrated that different Allium species may be useful for the prevention of pathological conditions such as liver necrosis, diabetes type 2, obesity, hypercholesterolemia, atherosclerosis, coronary heart disease, hypertension, carcinogenesis, pulmonary damages, cataract, depression and disturbances of the gastrointestinal tract [2]-[7].

The genus Allium is an important dietary source of antioxidant phytochemical products, vitamins, and different antioxidants and enzymes, which contribute to their nutritional and therapeutic characteristics [8] [9].

The beneficial effects of garlic (Allium sativum L.), at least in part, can be attributed to its ability to enhance or maintain the total antioxidant capacity of people who include these bulbs in their diet.

In previous studies, we have demonstrated that some Allium species (Allium neapolitanum Cyr., Allium subhirsutum L., Allium roseum L.), endemic to Italian flora, have an antioxidant activity, in vitro, similar or better than $A$. sativum [10] [11] [12]. We have also shown the protective effect of Allium neapolitanum Cyr. in rats with liver poisoning induced by ethanol [13].

The aim of this study is to compare the data of the antioxidant status of fresh organs (bulbs, bulblets, flowers bulblets, leaves and flowers) of wild Allium roseum, with the results obtained from bulbs and leaves of Allium sativum.

Hence we measured the antioxidant enzyme's activity (glutathione peroxidase, catalase and glutathione reductase), the levels of reduced and oxidized glutathione and the content of ascorbic acid, thiosulfinates, flavonols (rutin and quercetin) and soluble proteins in Allium roseum and in bulbs, and leaves of $\mathrm{Al}$ lium sativum.

\section{Materials and Methods}

All reagents were of analytical grade. HPLC standard substance (rutin, quercetin and ascorbic acid) were purchased from Sigma-Aldrich (St. Louis, Missouri) and HPLC solvents were purchased from Merck (Darmstadt, Germany). The other standard molecules and chemicals were purchased from Sigma-Aldrich (St. Louis, Missouri). Milli-Q (Millipore-Lab, Bedford, Massachusetts) purified water was used for all analyses.

\subsection{Plant Collection}

Two Allium species were studied: Allium sativum L. cultivated in rural farms of Poggibonsi (Siena-latitude $43^{\circ} 28^{\prime} 14^{\prime \prime} \mathrm{N}$ and longitude $11^{\circ} 08^{\prime} 52^{\prime \prime} \mathrm{E}$ ) and wild $A I$ lium roseum L. collected nearby Siena (Tuscany, Italy-latitude $43^{\circ} 16^{\prime} 27^{\prime \prime} \mathrm{N}$ and longitude $\left.11^{\circ} 18^{\prime} 50 " \mathrm{E}\right)$. The plants were collected respectively in March, 2017 and during their blooming time in May, 2017.

The identification of the sample of Allium roseum was performed by Dr. Ilaria Bonini and a voucher specimen (SIENA-N ${ }^{\circ} 11052$ ) was deposited in the Herba- 
rium Universitatis Senensis [SIENA], Department of Life Sciences, University of Siena.

\subsection{Processing of Samples}

Fresh organs (bulbs, bulblets, flowers bulblets, leaves and flowers) were cleaned to remove residual impurities; subsequently each part of the plant was cut and homogenized $(500 \mathrm{mg} / \mathrm{ml}$ ) in MilliQ purified water or a different buffer (as described below for each parameter) using a homogenizer (T25 Basic Ultra-Turrax, Janke \& Kunlel, IKA-Laboratechnik, Staufen, Germany).

Depending on the specific evaluation parameters, the homogenates were treated with opportune reagents and centrifuged to different gravities according to the several methods reported below. Subsequently, all supernatants were stored at $-80^{\circ} \mathrm{C}$ before starting their analytical procedures.

\section{Analytical Procedures}

\subsection{Ascorbic Acid}

The organs of plants were homogenized in phosphate buffer $\left(\mathrm{pH} \mathrm{7.4)}\right.$ at $0^{\circ} \mathrm{C}$. These solutions were added to an equal volume of $10 \%$ metaphosphoric acid and immediately centrifuged at $2000 \mathrm{~g} \times 10 \mathrm{~min}$ at $0^{\circ} \mathrm{C}$. Ascorbic acid (AA) was measured by the HPLC method [14]. The supernatants were removed and filtered (Millipore $0.45 \mu \mathrm{m}$, Merck, Darmstadt, Germany), and $20 \mu$ aliquots were manually injected into the high-performance liquid chromatography column (Reverse phase C18) with UV detector at $262 \mathrm{~nm}$. Results were expressed as $\mu$ moles/g of fresh and unprocessed weight.

\subsection{Quercetin and Rutin}

The organs of plants were homogenized in phosphate buffer $(\mathrm{pH} 7.4)$ at $0^{\circ} \mathrm{C}$. The samples were centrifuged at $2000 \mathrm{~g} \times 10 \mathrm{~min}$ at $0^{\circ} \mathrm{C}$. The supernatants were removed and filtered (Millipore $0.45 \mu \mathrm{m}$, Merck, Darmstadt, Germany). Quercetin $(\mathrm{Q})$ and rutin $(\mathrm{R})$ were measured by the HPLC method [15]. Twenty $\mu \mathrm{l}$ aliquots were manually injected into the high-performance liquid chromatography column (Reverse phase C18) with UV detector at $360 \mathrm{~nm}$. The eluent was $\left(\mathrm{CH}_{3} \mathrm{OH}: \mathrm{H}_{2} \mathrm{O}: \mathrm{H}_{3} \mathrm{PO}_{4}=60: 40: 0.4 \mathrm{v} / \mathrm{v}\right)$. Results were expressed as $\mu \mathrm{g} / \mathrm{g}$ of fresh and unprocessed weight.

\subsection{Thiosulfinates}

The plants' organs were homogenized in ice-cold phosphate buffer $0.125 \mathrm{M}(\mathrm{pH}$ 7.4) and this solution was centrifuged for $10 \mathrm{~min}$ at $0^{\circ} \mathrm{C}$ at low speed $(2000 \mathrm{~g})$. Total thiosulfinates (Thio) were measured in supernatants with a spectrophotometric procedure [16]. One molecule of allicin reacts rapidly with two molecules of cysteine to form two molecules of S-allil mercapto-cysteine. The decrease in cysteine concentrations is measured by reaction with DTNB 5,5'-dithiobis (2-nitrobenzoic acid) at $412 \mathrm{~nm}$. The results are expressed as $\mu \mathrm{mol} / \mathrm{g}$ of fresh and 
unprocessed weight.

\subsection{Glutathione Oxidized and Reduced}

The plants' organs were homogenized in ice-cold phosphate buffer $0.125 \mathrm{M}(\mathrm{pH}$ 7.4) containing $1 \mathrm{mM}$ EDTA and then were added to an equal volume metaphosphoric acid (10\%). Samples were centrifuged at low speed $(2000 \mathrm{~g}) \times 10 \mathrm{~min}$ at $0^{\circ} \mathrm{C}$. Reduced glutathione (GSH) and oxidized glutathione (GSSG) were quantified in supernatant by microassay procedure [17]. The results were expressed as $\mathrm{nmol} / \mathrm{mg}$ protein.

\subsection{Glutathione Reductase Activity}

The organs of the plant were homogenized in cold $0.25 \mathrm{M}$ sucrose in $0.1 \mathrm{M}$ phosphate buffer, $\mathrm{pH}$ 7.4. The homogenates were centrifuged at 40,000 $\mathrm{g} \times 20$ $\min$ at $4^{\circ} \mathrm{C}$, and the supernatants were used for the glutathione reductase (GR) assay [18]. The results were expressed as $\mathrm{U} / \mathrm{mg}$ protein.

\subsection{Glutathione Peroxidase Assay}

The organs of the plants were homogenized using the same method as described for GR. The glutathione peroxidase activity (GPx) was evaluated by measuring the change in absorbance at $340 \mathrm{~nm}$, at $37^{\circ} \mathrm{C}$, caused by the oxidation of NADPH [19]. Enzyme activity was expressed as U/mg of protein.

\subsection{Catalase Activity}

The organs of the plants were homogenized in ice-cold phosphate buffer $(0.125$ $\mathrm{M}, \mathrm{pH}$ 7.4) containing $1 \mathrm{mM}$ EDTA and then centrifuged at $4000 \mathrm{~g}$ for $15 \mathrm{~min}$ at $4^{\circ} \mathrm{C}$. Catalase (CAT) activity was determined by a microassay procedure [20]. The results were expressed as $\mathrm{nmol} / \mathrm{min} / \mathrm{mg}$ of protein.

\subsection{Proteins Assay}

Protein concentrations were determined by the Lowry method and the calibration curves were prepared with dry bovine serum albumin [21].

\section{Statistical Analysis}

Statistical analysis was performed with the SPSS version 19 software package (SPSS Inc, Chicago, IL, USA). Levene's test was used to assess if the groups have equal variances. One-way analysis of variance (ANOVA) was utilized to evaluate differences among the groups.

The Tukey's HSD test was mostly used for multiple comparisons when the assumption of homoscedasticity was respected, while Welch test and Games-Howell post hoc test were used when the assumption of homoscedasticity was violated.

The values of $\mathrm{p}<0.05$ were considered significant.

The correlations among variables were established using Spearman's rho correlation coefficients. 


\section{Results}

The activities of antioxidant enzymes (CAT, GPx and GR) and the relative levels of GSH, GSSG, Thio, and AA (expressed as mean \pm standard error) in the bulb and leaves of Allium sativum and in different fresh organs (bulbs, bulblets, flowers bulblets, leaves and flowers) of Allium roseum are reported in Table 1 and Table 2.

The data shows that Allium roseum possess effective antioxidant properties similar to garlic, however the values of enzymatic activities and the levels of non-enzymatic parameter are different in the various organs of the plant.

The highest activity of GPx (Table 1) is observed in the bulbs of Allium roseum when compared with the garlic's bulbs $(38.31 \pm 1.289 \mathrm{U} / \mathrm{mg}$ protein and $3.58 \pm 1.502 \mathrm{U} / \mathrm{mg}$ protein respectively, $\mathrm{p}<0.001)$. Similarly, GPx activity is greater in the bulbs $(38.31 \pm 1.289 \mathrm{U} / \mathrm{mg}$ protein $)$ than the flowers $(0.03 \pm 0.003$ $\mathrm{U} / \mathrm{mg}$ protein, $\mathrm{p}<0.01)$, the bulblets $(18.00 \pm 0.731 \mathrm{U} / \mathrm{mg}$ protein, $\mathrm{p}<0.01)$ and flowers bulblets $(1.74 \pm 0.131 \mathrm{U} / \mathrm{mg}$ protein, $\mathrm{p}<0.01)$ of Allium roseum.

Table 1. Antioxidant enzymes activity in different fresh organs (bulbs, bulblets, flowers bulblets, leaves and flowers) of Allium roseum and bulbs, leaves of Allium sativum.

\begin{tabular}{lcccc}
\hline \multicolumn{2}{c}{ Enzymes activity } & $\begin{array}{c}\text { CAT } \\
\text { nmol/min/mg protein }\end{array}$ & $\begin{array}{c}\text { GPx } \\
\text { U/mg protein }\end{array}$ & $\begin{array}{c}\text { GR } \\
\text { U/mg protein }\end{array}$ \\
\hline \multirow{2}{*}{ Allium } & Bulbs & $480.59 \pm 21.253$ & $3.58 \pm 1.502$ & $1.24 \pm 0.057$ \\
sativum & Leaves & $52.96 \pm 1.883^{\mathrm{a}}$ & $19.07 \pm 3.689$ & $3.44 \pm 0.156^{\mathrm{a}}$ \\
& Bulbs & $645.75 \pm 51.993$ & $38.31 \pm 1.289^{\mathrm{aaa}}$ & $4.40 \pm 0.151^{\mathrm{aa}}$ \\
Allium & Leaves & $318.85 \pm 12.311$ & $13.11 \pm 5.647$ & $1.07 \pm 0.019^{\mathrm{bb}}$ \\
roseum & Flowers & $65.49 \pm 2.133^{\mathrm{a} ; \mathrm{b}}$ & $0.03 \pm 0.003^{\mathrm{bb}}$ & $1.05 \pm 0.013^{\mathrm{bb}}$ \\
& Bulblets & $99.41 \pm 5.776^{\mathrm{aa} ; \mathrm{b}}$ & $18.00 \pm 0.731^{\mathrm{a} ; \mathrm{bb}}$ & $1.61 \pm 0.018^{\mathrm{bb}}$ \\
& Flowers Bulblets & $100.16 \pm 2.517^{\mathrm{a} b \mathrm{~b}}$ & $1.74 \pm 0.131^{\mathrm{bb}}$ & $1.22 \pm 0.078^{\mathrm{bbb}}$ \\
\hline
\end{tabular}

The values are expressed as mean \pm standard error. ${ }^{a} \mathrm{p}<0.05$; ${ }^{\text {aa }} \mathrm{p}<0.01$; ${ }^{\text {aaa }} \mathrm{p}<0.001$ compared with Allium sativum bulbs. ${ }^{\mathrm{b}} \mathrm{p}<0.05 ;{ }^{\mathrm{bb}} \mathrm{p}<0.01 ;{ }^{\mathrm{bbb}} \mathrm{p}<0.001$ compared with Allium roseum bulbs.

Table 2. Non-enzymatic antioxidants in different fresh organs (bulbs, bulblets, flowers bulblets, leaves and flowers) of Allium roseum and bulbs, leaves of Allium sativum.

\begin{tabular}{cccccc}
\hline \multicolumn{2}{c}{ Antioxidant content } & GSH & GSSG & AA & Thio \\
\hline Allium & Bulbs & $4.23 \pm 0.445$ & $1.34 \pm 0.163$ & $0.23 \pm 0.003$ & $14.25 \pm 1.157$ \\
sativum & Leaves & $0.66 \pm 0.025^{\mathrm{aaa}}$ & $0.46 \pm 0.013$ & $0.49 \pm 0.006^{\mathrm{aaa}}$ & $10.28 \pm 1.158$ \\
& Bulbs & $9.80 \pm 0.061^{\mathrm{a}}$ & $3.04 \pm 0.121^{\mathrm{a}}$ & $0.28 \pm 0.002^{\mathrm{aa}}$ & $0.65 \pm 1.0 .168^{\mathrm{a}}$ \\
\multirow{2}{*}{ Allium } & Leaves & $1.68 \pm 0.091^{\mathrm{bbb}}$ & $0.71 \pm 0.028^{\mathrm{bb}}$ & $1.25 \pm 0.047^{\mathrm{aa} b \mathrm{~b}}$ & $0.75 \pm 0.289^{\mathrm{a}}$ \\
roseum & Flowers & $2.15 \pm 0.029^{\mathrm{bbb}}$ & $1.57 \pm 0.096^{\mathrm{bb}}$ & $1.94 \pm 0.047^{\mathrm{aa} ; \mathrm{bb}}$ & $18.87 \pm 1.216^{\mathrm{b}}$ \\
& Bulblets & $0.73 \pm 0.038^{\mathrm{bbb}}$ & $0.33 \pm 0.001^{\mathrm{bb}}$ & $0.79 \pm 0.021^{\mathrm{aa} b \mathrm{bb}}$ & $3.04 \pm 0.093^{\mathrm{bb}}$ \\
& Flowers & $2.52 \pm 0.025^{\mathrm{bbb}}$ & $1.51 \pm 0.029^{\mathrm{b}}$ & $0.45 \pm 0.006^{\mathrm{aaa} ; \mathrm{bb}} 35.46 \pm 0.976^{\mathrm{aa} ; \mathrm{bb}}$ \\
& Bulblets & & &
\end{tabular}

The values are expressed as mean \pm standard error. ${ }^{a} \mathrm{p}<0.05 ;{ }^{\text {aa }} \mathrm{p}<0.01$; ${ }^{\text {aaa }} \mathrm{p}<0.001$ compared with Allium sativum bulbs. ${ }^{\mathrm{b}} \mathrm{p}<0.05 ;{ }^{\mathrm{bb}} \mathrm{p}<0.01 ;{ }^{\mathrm{bbb}} \mathrm{p}<0.001$ compared with Allium roseum bulbs. 
The highest activity of CAT (Table 1) is observed in the bulbs of Allium roseum $(645.75 \pm 51.993 \mathrm{nmol} / \mathrm{min} / \mathrm{mg}$ protein) when compared with flowers $(65.49$ $\pm 2.133 \mathrm{nmol} / \mathrm{min} / \mathrm{mg}$ protein $\mathrm{p}<0.05)$, bulblets $(99.41 \pm 5.776 \mathrm{nmol} / \mathrm{min} / \mathrm{mg}$ protein $\mathrm{p}<0.05)$ and flowers bulblets $(100.16 \pm 2.517 \mathrm{nmol} / \mathrm{min} / \mathrm{mg}$ protein $\mathrm{p}<$ 0.05) of Allium roseum. No statistical significance is observed when activity of CAT in the bulbs of Allium roseum was compared to garlic bulbs.

It is remarkable that the high activity for GR observed in the bulbs of Allium roseum $(4.40 \pm 0.151, \mathrm{p}<0.01)$ is greater than bulbs of Allium sativum (Table $1)$. Finally, Allium roseum shows the GR activity greater in the bulbs $(4.40 \pm$ $0.151 \mathrm{U} / \mathrm{mg}$ protein) than leaves $(1.07 \pm 0.019 \mathrm{U} / \mathrm{mg}$ protein, $\mathrm{p}<0.01)$, flowers $(1.05 \pm 0.013 \mathrm{U} / \mathrm{mg}$ protein, $\mathrm{p}<0.01)$, bulblets $(1.61 \pm 0.018 \mathrm{U} / \mathrm{mg}$ protein, $\mathrm{p}<$ $0.01)$ and flowers bulblets $(1.22 \pm 0.078 \mathrm{U} / \mathrm{mg}$ protein, $\mathrm{p}<0.001)$.

The highest levels of GSH (Table 2) are showed in the bulbs of Allium roseum $(9.80 \pm 0.061 \mathrm{nmol} / \mathrm{mg}$ protein, $\mathrm{p}<0.05)$ when compared to bulbs of Allium sativum (4.23 $\pm 0.445 \mathrm{nmol} / \mathrm{mg}$ protein).

However, GSH levels are greater in the bulbs of Allium roseum $(\mathrm{p}<0.001)$ when compared to leaves $(1.68 \pm 0.091 \mathrm{nmol} / \mathrm{mg}$ protein $)$ flowers $(2.15 \pm 0.029$ $\mathrm{nmol} / \mathrm{mg}$ protein), bulbets $(0.73 \pm 0.038 \mathrm{nmol} / \mathrm{mg}$ protein) and flowers bulblets $(2.52 \pm 0.025 \mathrm{nmol} / \mathrm{mg}$ protein). The levels of GSSG show the same trend of reduced form. The highest levels of GSSG are found in the bulbs of Allium roseum $(3.04 \pm 0.121 \mathrm{nmol} / \mathrm{mg}$ protein; $\mathrm{p}<0.05)$ when compared to bulbs of Allium sativum (Table 2). GSSG levels are greater in the bulbs of Allium roseum when compared to leaves $(0.71 \pm 0.028 \mathrm{nmol} / \mathrm{mg}$ protein $)$, flowers $(1.57 \pm 0.096 \mathrm{nmol} / \mathrm{mg}$ protein), bulblets $(0.33 \pm 0.001 \mathrm{nmol} / \mathrm{mg}$ protein $)$ ( $\mathrm{p}<0.001$ respectively) and flowers bulblets $(1.51 \pm 0.029 \mathrm{nmol} / \mathrm{mg}$ protein, $\mathrm{p}<0.05)$.

Different results are found for Thio levels (Table 2). The highest levels of Thio are found in the flowers bulblets of Allium roseum $(35.46 \pm 0.976, \mathrm{p}<0.01)$ when compared to bulbs of Allium sativum (14.25 \pm 1.158$)$, or when compared to bulbs $(0.65 \pm 0.168 \mu \mathrm{mol} / \mathrm{g}$ of fresh weight, $\mathrm{p}<0.01)$ of Allium roseum. However, leaves $(0.75 \pm 0.289 \mu \mathrm{mol} / \mathrm{g}$ of fresh weight $)$, flowers $(18.87 \pm 1.216 \mu \mathrm{mol} / \mathrm{g}$ of fresh weight), and bulblets $(3.04 \pm 0.093 \mu \mathrm{mol} / \mathrm{g}$ of fresh weight $),(\mathrm{p}<0.01$ respectively) of Allium roseum showed higher levels of Thio respect to Allium roseum bulbs. Moreover, the highest levels of Thio are shown in the bulbs of $A I$ lium roseum when compared to bulbs of Allium sativum ( $<<0.05)$.

An interesting result was noted with AA levels. The highest content of AA (Table 2) is in flowers of Allium roseum (1.94 $\pm 0.047 \mu \mathrm{mol} / \mathrm{g}$ of fresh weight) when compared to bulbs of Allium sativum $(0.23 \pm 0.003, \mathrm{p}<0.01)$ or when compared to bulbs $(0.28 \pm 0.002 \mu \mathrm{mol} / \mathrm{g}$ of fresh weight, $\mathrm{p}<0.01)$ of Allium roseum. Furthermore, the leaves $(1.25 \pm 0.048 \mu \mathrm{mol} / \mathrm{g}$ of fresh weight, $\mathrm{p}<0.05)$, bulblets $(0.79 \pm 0.021 \mu \mathrm{mol} / \mathrm{g}$ of fresh weight $)$ and flowers bulblets $(0.45 \pm 0.006$ $\mu \mathrm{mol} / \mathrm{g}$ of fresh weight), ( $\mathrm{p}<0.01$ respectively) of Allium roseum also have a higher AA content than the bulbs of Allium roseum. However, the highest levels of AA are shown in the bulbs of Allium roseum when compared to bulbs of $A l$ lium sativum $(\mathrm{p}<0.01)$. 
Table 3 shows $\mathrm{R}$ and $\mathrm{Q}$ content in different organs of Allium species investigated. We found that the flavonols content ( $\mu \mathrm{g} / \mathrm{g}$ of fresh weight) was significantly higher in the flowers, where R was fifty times higher than Q $(272.68 \pm$ 28.083 and $4.13 \pm 0.261$ respectively, $\mathrm{p}<0.001$ ).

Allium roseum shows R content greater in the flowers $(272.68 \pm 28.083)$ than bulbs $(3.89 \pm 0.412, \mathrm{p}<0.01)$. Moreover, the content of $\mathrm{R}$ is significantly higher in the bulbs of Allium roseum than bulbs of Allium sativum (3.89 \pm 0.412 and $3.55 \pm 0.819$ respectively; $\mathrm{p}<0.05$ ).

Also the content of $\mathrm{Q}$ is significantly higher $(\mathrm{p}<0.001)$ in the flowers of $A 1-$ lium roseum (4.13 \pm 0.261$)$ than bulbs of Allium sativum (1.39 \pm 0.140$)$ or the other organs of Allium roseum. No significant difference was observed between $\mathrm{Q}$ levels in the other organs investigated of Allium roseum respect to bulbs of Allium sativum.

Moreover, by evaluating the antioxidant content in the leaves of Allium sativum with respect to the bulbs of Allium sativum, it should be noted that the content of CAT, GR, GSH, AA, R is significantly higher in the leaves (Tables 1-3).

Finally, in Table 4 the correlation between the levels of AA, flavonols ( $\mathrm{R}$ and Q), Thio, GSH, GSSG and the antioxidant enzymatic activities (GR, GPx and CAT) in Allium species are reported. A significantly negative correlation was observed between the levels of AA and CAT, GR, GSH and GSSG, while the flavonoid content is positively correlated with the levels of non-enzymatic antioxidants and negatively correlated with the activity of antioxidant enzymes.

\section{Discussion}

In this study we observed a high content of antioxidants in every fresh organ of Allium roseum that could play a fundamental role in the nutritional and therapeutic field.

There is no research or study comparing the enzymatic and non-enzymatic antioxidant defence system of fresh organs of Allium sativum and Allium roseum.

Table 3. Rutin and quercetin content in various fresh organs (bulbs, bulblets, flowers bulblets, leaves and flowers) of Allium roseum and bulbs, leaves of Allium sativum.

\begin{tabular}{cccc}
\hline \multicolumn{2}{c}{ Sample } & Rutin & Quercetin \\
\hline Allium & Bulbs & $3.55 \pm 0.819$ & $1.39 \pm 0.140$ \\
sativum & Leaves & $61.15 \pm 9.131^{\mathrm{aa}}$ & $1.21 \pm 0.139$ \\
& Bulbs & $3.89 \pm 0.412^{\mathrm{a}}$ & $1.48 \pm 0.101$ \\
\multirow{2}{*}{ Allium } & Leaves & $5.33 \pm 0.691$ & $1.43 \pm 0.108$ \\
roseum & Flowers & $272.68 \pm 28.083^{\mathrm{aa}}$ & $4.13 \pm 0.261^{\mathrm{aaa}}$ \\
& Bulblets & $3.34 \pm 0.594$ & $1.06 \pm 0.701$ \\
& Flowers Bulblets & $12.12 \pm 1.210^{\mathrm{aa}}$ & $1.68 \pm 0.233$ \\
\hline
\end{tabular}

The values are expressed as $\mu \mathrm{g} / \mathrm{g}$ of fresh weight ( \pm standard error). ${ }^{\mathrm{a}} \mathrm{p}<0.05$; ${ }^{\text {aa }} \mathrm{p}<0.01$; ${ }^{\text {aaa }} \mathrm{p}<0.001$ compared with Allium sativum bulbs 
Table 4. Correlations (rho Spearman's coefficient) between flavonols, thiosulfinates and antioxidant capacities in Allium species.

\begin{tabular}{cccccccccc}
\hline & $\mathbf{R}$ & $\mathrm{Q}$ & Thio & AA & GPx & CAT & GR & GSH & GSSG \\
\hline R & 1 & & & & & & & & \\
Q & $0.337^{*}$ & 1 & & & & & & & \\
Thio & $0.411^{* *}$ & $0.332^{*}$ & 1 & & & & & & \\
AA & $0.383^{*}$ & 0.136 & -0.283 & 1 & & & & & \\
GPx & -0.273 & $-0.359^{*}$ & $-0.698^{* * *}$ & -0.016 & 1 & & & & \\
CAT & $0.686^{* * *}$ & 0.032 & -0.302 & $-0.520^{* * *}$ & 0.100 & 1 & & & \\
GR & -0.189 & $-0.374^{*}$ & -0.211 & $-0.427^{* *}$ & $0.705^{* * *}$ & 0.010 & 1 & & \\
GSH & $-0.333+$ & $0.350^{*}$ & 0.242 & $-0.623^{* * *}$ & -0.274 & $0.765^{* * *}$ & -0.070 & 1 & \\
GSSG & 0.103 & $0.487^{* *}$ & $0.334^{*}$ & $-0.404^{* *}$ & $-0.322^{*}$ & $0.503^{* * *}$ & -0.129 & $0.865^{* * *}$ & 1 \\
\hline
\end{tabular}

Legend: Thio (thiosulfinates $\mu \mathrm{mol} / \mathrm{g}$ of fresh); AA (ascorbic acid $\mu \mathrm{mol} / \mathrm{ml}$ ); GPx (glutathione peroxidase activity $\mathrm{U} / \mathrm{mg}$ protein); CAT (catalase activity $\mathrm{nmol} / \mathrm{min} / \mathrm{mg}$ protein); GR (glutathione reductase activity $\mathrm{U} / \mathrm{mg}$ Protein); GSH (glutathione reduced form $\mathrm{nmol} / \mathrm{mg}$ protein); GSSG (glutathione oxidized form $\mathrm{nmol} / \mathrm{mg}$ protein); R (rutin $\mu \mathrm{g} / \mathrm{g}$ of fresh weight); $\mathrm{Q}$ (quercetin $\mu \mathrm{g} / \mathrm{g}$ of fresh weight) $\left({ }^{*} \mathrm{p}<0.05\right.$; ${ }^{* *} \mathrm{p}<0.01$; $\left.{ }^{* * *} \mathrm{p}<0.001\right)$.

Moreover, this is the first time that flavonols were measured in accordance with antioxidant activity. Current evidence indicates that consumption of fruit and vegetables decreases the incidence of the most prominent diseases in developed countries [22]. There is an increased importance in identifying dietary plant compounds or spices as a source of natural antioxidants [23].

Our data shows that the bulbs of Allium roseum are rich in antioxidant substances so that they could be used in the medical field in the same way that bulbs of Allium sativum are already being used. Similarly to garlic, the bulbs of Allium roseum have the highest levels of GSH, GSSG and Thio revealing that also Allium roseum is rich in sulphur compounds, which are also the source of many health-promoting effects. The high levels of Thio in the bulbs, leaves and flowers bulblets of Allium roseum suggest also its possible use as a source of sulphur species. Certainly the presence of many reactive sulphur species are related to interesting biological activity in vivo, as antimicrobial, fungicidal, antiplatelet or anticancer activity [6] [24] [25]. In the plants sulphur compounds have many roles similar to those observed in mammalian cells [26]. The high level of AA in the flowers and others organs of the Allium roseum suggests that ascorbic acid plays an essential role in the plant's antioxidant properties. In addition, AA is also related with cell division in plants and as a regulator for cellular processes including cell wall metabolism [27]. GPx, GR and CAT plays a key role in the response to oxidative stress by maintaining the functions like an antioxidant that scavenges reactive oxygen species, such as hydrogen peroxide and superoxide [28]. The higher activity of GPx and GR in Allium roseum compared to Allium sativum strengthens the antioxidant capacity of the Allium roseum bulbs. $\mathrm{R}$ is a flavonoid that is widely found in fruits and vegetables and the high levels observed bulbs, flowers bulblets and especially in flowers of Allium roseum make it 
a potential new sources for this bioactive compound with therapeutic and nutritive purposes [29]. Some studies investigate the possible uses of Allium flowers for their nutritional and health properties [30] [31]. Higher levels of AA, GSH, R and the elevated activity of GR and CAT were found in the garlic leaves, in comparison to the bulbs, and this provides new information for Allium sativum, particularly because the leaves are less used and investigated. Recently, interest in the wild Allium species has grown and these results provide new information for the Allium roseum, a wild-growing Allium species, which is less studied and the references to nutritional and medical applications are rarely given [29] [32] [33] [34].

\section{Conclusions}

Results suggest that the investigated Allium species can serve as a cost-effective source of high-value antioxidant nutraceuticals for protection against oxidative stress-related disorders.

Allium roseum displays antioxidant abilities in all investigated plant organs, especially in the bulbs. They are the organs with higher enzyme activity compared to the other organs of the plant. Moreover, the content of AA, GSH, GSSG, Thio and $\mathrm{R}$, is important factors in determining the antioxidant activity of this plant.

Our research indicates that increased consumption of these garlic species can provide health benefits and prevent diseases associated with oxidative stress. Moreover, because of their described properties, all investigated plant organs can be used as new ingredients to improve diversity in the modern diet as wells as in the industries for manufacturing products with antioxidant activity.

Thus, the presented results indicated that Allium roseum exhibited antioxidant ability in all investigated plant organs especially in the bulbs and therefore bulbs could be used in the human diet as a source of natural antioxidants. Finally, all investigated Allium roseum organs could be used also in the pharmaceuti$\mathrm{cal}$ and cosmetic industry for manufacturing products with potent oxygen radical scavenger activity.

\section{Acknowledgements}

The present research was supported by funds of the University of Siena.

\section{Conflicts of Interest}

The authors declare no conflicts of interest regarding the publication of this paper.

\section{References}

[1] Perez-Gregorio, R. and Simal-Gandara, J. (2017) A Critical Review of Bioactive Food Components, and of Their Functional Mechanisms, Biological Effects and Health Outcomes. Current Pharmaceutical Design, 23, 2731-2741. https://doi.org/10.2174/1381612823666170317122913 
[2] Bradley, J.M., Organ, C.L. and Lefer, D.J. (2016) Garlic-Derived Organic Polysulfides and Myocardial Protection. The Journal of Nutrition, 146, 403S-409S. https://doi.org/10.3945/jn.114.208066

[3] de Giorgio, A. and Stebbing, J. (2016) Garlic: A Stake through the Heart of Cancer? The Lancet Oncology, 17, 879-880. https://doi.org/10.1016/S1470-2045(16)30235-2

[4] Butt, M.S., Sultan, M.T., Butt, M.S. and Iqbal, J. (2009) Garlic: Nature's Protection against Physiological Threats. Critical Reviews in Food Science and Nutrition, 49, 538-551. https://doi.org/10.1080/10408390802145344

[5] Cao, H.X., Zhu, K.X., Fan, J.G. and Qiao, L. (2014) Garlic-Derived Allyl Sulfides in Cancer Therapy. Anti-Cancer Agents in Medicinal Chemistry, 14, 793-799. https://doi.org/10.2174/1871520614666140521120811

[6] Shouk, R., Abdou, A., Shetty, K., Sarkar, D. and Eid, A.H. (2014) Mechanisms Underlying the Antihypertensive Effects of Garlic Bioactives. Nutrition Research, 34, 106-115. https://doi.org/10.1016/j.nutres.2013.12.005

[7] Tavakkoli-Kakhki, M., Motavasselian, M., Mosaddegh, M., Esfahani, M.M., Kamalinejad, M. and Nematy, M. (2014) Food-Based Strategies for Depression Management from Iranian Traditional Medicine Resources. Iranian Red Crescent Medical Journal, 16, e14151. https://doi.org/10.5812/ircmj.14151

[8] Zheng, J., Zhou, Y., Li, Y., Xu, D.P., Li, S. and Li, H.B. (2016) Spices for Prevention and Treatment of Cancers. Nutrients, 8, E495. https://doi.org/10.3390/nu8080495

[9] Fenwick, G.R. and Hanley, A.B. (1985) The Genus Allium. Part 2. Critical Reviews in Food Science and Nutrition, 22, 273-377. https://doi.org/10.1080/10408398509527417

[10] Nencini, C., Cavallo, F., Capasso, A., Franchi, G.G., Giorgi, G. and Micheli, L. (2007) Evaluation of Antioxidative Properties of Allium Species Growing Wild in Italy. Phytotherapy Research, 21, 874-878. https://doi.org/10.1002/ptr.2168

[11] Nencini, C., Menchiari, A., Franchi, G.G. and Micheli, L. (2011) In Vitro Antioxidant Activity of Aged Extracts of Some Italian Allium Species. Plant Foods for $\mathrm{Hu}$ man Nutrition, 66, 11-16. https://doi.org/10.1007/s11130-010-0204-2

[12] Micheli, L., Nencini, C. and Menchiari, A. (2015) Evaluation of Antioxidant Defense System of Wild Allium neapolitanum Cyr. from Italy. The Pharma Innovation Journal, 4, 56-60.

[13] Nencini, C., Franchi, G.G., Cavallo, F. and Micheli, L. (2010) Protective Effect of Allium neapolitanum Cyr. versus Allium sativum L. on Acute Ethanol-Induced Oxidative Stress in Rat Liver. Journal of Medicinal Food, 13, 329-335. https://doi.org/10.1089/jmf.2008.0180

[14] Ross, M.A. (1994) Determination of Ascorbic Acid and Uric Acid in Plasma by High-Performance Liquid Chromatography. Journal of Chromatography B Biomedical Sciences and Applications, 657, 197-200. https://doi.org/10.1016/0378-4347(94)80087-1

[15] Jia, Z., Tang, M. and Wu, J. (1999) The Determination of Flavonoid Contents in Mulberry and Their Scavenging Effects on Superoxide Radicals. Food Chemistry, 64, 555-559. https://doi.org/10.1016/S0308-8146(98)00102-2

[16] Han, J., Lawson, L., Han, G. and Han, P. (1995) A Spectrophotometric Method for Quantitative Determination of Allicin and Total Garlic Thiosulfinates. Analytical Biochemistry, 225, 157-160. https://doi.org/10.1006/abio.1995.1124

[17] Nencini, C., Giorgi, G. and Micheli, L. (2007) Protective Effect of Silymarin on Oxidative Stress in Rat Brain. Phytomedicine, 14, 129-135. 
https://doi.org/10.1016/j.phymed.2006.02.005

[18] Cribb, A.E., Leeder, J.S. and Spielberg, S.P. (1989) Use of a Microplate Reader in an Assay of Glutathione Reductase Using 5,5'-dithiobis(2-nitrobenzoic acid). Analytical Biochemistry, 183, 195-196. https://doi.org/10.1016/0003-2697(89)90188-7

[19] Flohé, L. and Günzler, W.A. (1984) Assays of Glutathione Peroxidase. Methods in Enzymology, 105, 114-121. https://doi.org/10.1016/S0076-6879(84)05015-1

[20] Johansson, H. and Borg, L.A.H. (1988) A Spectrophotometric Method for Determination of Catalase Activity in Small Tissue Samples. Analytical Biochemistry, 174, 331-336. https://doi.org/10.1016/0003-2697(88)90554-4

[21] Lowry, O.H., Rosebrough, N.J., Farr, A.L. and Randall, R.J. (1951) Protein Measurement with the Folin Phenol Reagent. The Journal of Biological Chemistry, 193, 265-275.

[22] Bvenura, C. and Sivakumar, D. (2017) The Role of Wild Fruits and Vegetables in Delivering a Balanced and Healthy Diet. Food Research International, 99, 15-30. https://doi.org/10.1016/j.foodres.2017.06.046

[23] Romojaro, A., Botella, M.A., Obón, C. and Pretel, M.T. (2013) Nutritional and Antioxidant Properties of Wild Edible Plants and Their Use as Potential Ingredients in the Modern Diet. International Journal of Food Sciences and Nutrition, 64, 944-952. https://doi.org/10.3109/09637486.2013.821695

[24] Bloem, E., Haneklaus, S. and Schnug, E. (2010) Influence of Fertilizer Practices on S-Containing Metabolites in Garlic (Allium sativum L.) under Field Conditions. Journal of Agricultural and Food Chemistry, 58, 10690-10696. https://doi.org/10.1021/jf102009j

[25] Beretta, H.V., Bannoud, F., Insani, M., Berli, F., Hirschegger, P., Galmarini, C.R. and Cavagnaro, P.F. (2017) Relationships between Bioactive Compound Content and the Antiplatelet and Antioxidant Activities of Six Allium Vegetable Species. Food Technology and Biotechnology, 55, 266-275.

[26] Noctor, G., Mhamdi, A., Chaouch, S., Han, Y., Neukermans, J., Marquez-Garcia, B., Queval, G. and Foyer, C.H. (2012) Glutathione in Plants: An Integrated Overview. Plant, Cell \& Environment, 35, 454-484. https://doi.org/10.1111/j.1365-3040.2011.02400.x

[27] Tóth, S.Z., Schansker, G. and Garab, G. (2013) The Physiological Roles and Metabolism of Ascorbate in Chloroplasts. Physiologia Plantarum, 148, 161-175. https://doi.org/10.1111/ppl.12006

[28] Csiszár, J., Lantos, E., Tari, I., Madoşă, E., Wodala, B., Vashegyi, Á., Horváth, F., Pécsváradi, A., Szabó, M., Bartha, B., Gallé, Á., Lazăr, A., Coradini, G., Staicu, M., Postelnicu, S., Mihacea, S., Nedelea, G. and Erdei, L. (2007) Antioxidant Enzyme Activities in Allium Species and Their Cultivars under Water Stress. Plant, Soil and Environment, 53, 517-523. https://doi.org/10.17221/2192-PSE

[29] Jeong, H.J., Yoou, M.S., Han, N.R., Hwang, S.Y., Yoon, K.W. and Kim, H.M. (2018) The New Therapeutic Herbal Drug HM0601 and Its Bioactive Compound Rutin Exert Potent Anti-Proliferative Activities in Mast Cells. Fundamental \& Clinical Pharmacology, 32, 279-287. https://doi.org/10.1111/fcp.12350

[30] D'Antuono, L.F. and Manco, M.A. (2013) Preliminary Sensory Evaluation of Edible Flowers from Wild Allium Species. Journal of the Science of Food and Agriculture, 93, 3520-3523. https://doi.org/10.1002/jsfa.6291

[31] Mskhiladze, L., Legault, J., Lavoie, S., Mshvildadze, V., Kuchukhidze, J., Elias, R. and Pichette, A. (2008) Cytotoxic Steroidal Saponins from the Flowers of Allium leucanthum. Molecules, 13, 2925-2934. https://doi.org/10.3390/molecules13122925 
[32] Ben Haj Said, L., Najjaa, H., Farhat, A., Neffati, M. and Bellagha, S. (2015) Thin Layer Convective Air Drying of Wild Edible Plant (Allium roseum) Leaves: Experimental Kinetics, Modeling and Quality. Journal of Food Science and Technology, 52, 3739-3749. https://doi.org/10.1007/s13197-014-1435-2

[33] Najjaa, H., Zria, K., Fattouch, S., Ammar, E. and Neffati, M. (2011) Antioxidant and Antimicrobial Activities of Allium roseum L. "Lazoul," A Wild Edible Endemic Species in North Africa. Properties of Science Food, 14, 371-380. https://doi.org/10.1080/10942910903203164

[34] Souid, S., Najjaa, H., Riahi-Chebbi, I., Haoues, M., Neffati, M., Arnault, I., Auger, J., Karoui, H., Essafi, M. and Essafi-Benkhadir, K. (2017) Allium roseum L. Extract Exerts Potent Suppressive Activities on Chronic Myeloid Leukemia K562 Cell Viability through the Inhibition of BCR-ABL, PI3K/Akt, and ERK1/2 Pathways and the Abrogation of VEGF Secretion. Nutrition and Cancer, 69, 117-130. https://doi.org/10.1080/01635581.2017.1248295 